\title{
PENGARUH EARNING PER SHARE, DEBT TO EQUITY RATIO DAN PRICE EARNING RATIO TERHADAP HARGA SAHAM \\ PERUSAHAAN SEKTOR MAKANAN DAN MINUMAN YANG TERDAFTAR DI BURSA EFEK INDONESIA PERIODE 2013 - 2017
}

\author{
Arie Agustinus \\ Program Studi Magister Manajemen Universitas Tarumanagara \\ arie.agustinus@yahoo.com \\ Carunia Mulya Firdausy \\ Program Studi Magister Manajemen Universitas Tarumanagara
}

Masuk : 13-11-2019, revisi : 04-02-2020 diterima untuk diterbitkan : 05-02-2020

\begin{abstract}
The purpose of this research is to find out the influence of Earning Per Share, Debt to Equity Ratio, and Price Earning Ratio on the stock price of food and beverage companies listed in the Indonesia Stock Exchange for the period 2013 to 2017. The research sample consists of 12 companies, that were selected by using a purposive technique sampling method for the period of 2013-2017. The method to analyse the research questions was by using the statistical method of multiple linear regression method. The result found that Earning Per Share and Price Earning Ratio partially have significant influences on the stock price. Whilst Debt to Equity Ratio partially doesn't have a significant influence. However, Earning Per Share, Debt to Equity Ratio, and Price Earning Ratio have joint effects on the stock price of the food and beverage companies. The coefficient determination of this model was found to be about only $21,9 \%$. This suggests that the three independent variables underestimated have a lack of explanatory power of the stock price of food and beverage companies. Hence, further studies to seek other independent variables in the model are suggested to improve the model underestimated.
\end{abstract}

\begin{abstract}
Abstrak : Tujuan dari penelitian ini adalah untuk mengetahui pengaruh Earning Per Share, Debt to Equity Ratio, dan Price Earning Ratio terhadap harga saham perusahaan makanan dan minuman yang terdaftar di Bursa Efek Indonesia untuk periode 2013 hingga 2017. Sampel penelitian, terdiri dari 12 perusahaan, dipilih dengan menggunakan metode teknik purposive sampling dengan periode penelitian 2013-2017. Metode untuk menganalisis pertanyaan penelitian adalah dengan menggunakan metode statistik regresi linier berganda. Hasil penelitian menemukan bahwa, Earning Per Share dan Price Earning Ratio secara parsial berpengaruh signifikan terhadap harga saham. Sementara Debt to Equity Ratio secara parsial tidak memiliki pengaruh yang signifikan. Namun Earning Per Share, Debt to Equity Ratio, dan Price Earning Ratio secara bersama-sama mempunyai pengaruh terhadap harga saham perusahaan makanan dan minuman. Koefisien determinasi model ini hanya 21,9\%. Ini menunjukkan bahwa ketiga variabel independen tersebut memiliki kurangnya pengaruh terhadap harga saham perusahaan makanan dan minuman. Oleh karena itu, penelitian lebih lanjut untuk mencari variabel independen lain yang dapat meningkatkan pengaruh terhadap harga saham yang tidak diestimasi dalam model ini.
\end{abstract}

Keywords : Earnings per Share, Debt to Equity Ratio, Price Earnings Ratio and Stock Price 


\section{PENDAHULUAN}

Pertumbuhan ekonomi Indonesia banyak didukung dari berbagai sektor industri. Salah satu sektor industri yang cukup besar memberikan pengaruh dalam pertumbuhan ekonomi Indonesia adalah industri makanan dan minuman. Pada tahun 2014 harga saham industri makanan dan minuman sempat mengalami stagnan. Hal ini antara lain karena tidak stabilnya kondisi perekonomian sebagai akibat pelemahan nilai tukar rupiah terhadap dolar AS, bunga pinjaman bank yang naik, serta adanya kondisi Pemilihan Umum pada tahun 2014. Namun, setelah melewati tahun 2014, harga saham industri makanan dan minuman kembali meningkat terlihat dari semakin menjamurnya industri makanan dan minuman di Indonesia.

Kenaikan harga saham industri makanan dan minuman tersebut menarik untuk dikaji lebih lanjut faktor penyebabnya. Oleh karena itu, penelitian ini ditujukan apakah Earning Per Share, Debt to Equity Ratio dan Price Earning Ratio merupakan tiga variabel yang memberikan pengaruh terhadap harga saham industri makanan dan minuman.

\section{TUJUAN PENELITIAN}

Tujuan dari penelitian ini adalah untuk mengetahui pengaruh Earning Per Share (EPS), Debt to Equity Ratio (DER) dan Price Earning Ratio (PER) terhadap harga saham pada perusahaan makanan dan minuman yang terdaftar pada Bursa Efek Indonesia untuk periode 2013-2017 baik secara parsial maupun bersama-sama.

\section{TINJAUAN PUSTAKA DAN HIPOTESIS}

Weston dan Bringham (2010) menyatakan bahwa faktor-faktor yang mempengaruhi harga saham antara lain adalah Earning Per Share (EPS), tingkat bunga, jumlah kas deviden yang diberikan, jumlah laba yang didapat perusahaan, dan tingkat risiko dan pengembalian. Beberapa studi empirik untuk mengkaji faktor-faktor yang berpengaruh pada harga saham antara lain :

Stella (2009) dalam penelitiannya yang berjudul Pengaruh Price Earning Ratio (PER), Debt to Equity Ratio (DER) dan Price to Book Value (PBV) terhadap Harga Saham Perusahaan LQ-45 Yang Terdaftar Di Bursa Efek Indonesia Periode 2012-2006. Hasilnya adalah Price Earning Ratio (PER) memiliki pengaruh signifikan terhadap harga saham, sedangkan Debt to Equity Ratio (DER) dan Price to Book Value (PBV) tidak memiliki pengaruh signifikan terhadap harga saham.

Sedangkan Safitri (2013) dalam penelitiannya yang berjudul Pengaruh Earning Per Share, Price Earning Ratio, Return On Asset, Debt to Equity Ratio dan Market Value Added Terhadap Harga Saham Dalam Kelompok Jakarta Islamic Index. Disimpulkan bahwa secara parsial hanya variabel Earning Per Share, Price Earning Ratio, dan Market Value Added berpengaruh positif signifikan terhadap harga saham sedangkan Return On Asset dan Debt to Equity Ratio tidak mempunyai pengaruh signifikan terhadap harga saham dalam kelompok Jakarta Islamic Index (JII) tahun 2008-2013. Secara simultan variabel Earning Per Share, Price Earning Ratio, Return On Asset, Debt to Equity Ratio, dan Market Value Added mempunyai pengaruh signifikan terhadap harga saham dalam kelompok Jakarta Islamic Index (JII) tahun 2008-2011.

Demikian pula dengan Hutami (2012) dengan penelitiannya yang berjudul Pengaruh Deviden Per Shares, Return On Equity dan Net Profit Margin Terhadap Harga Saham Perusahaan Industri Manufaktur Yang Tercatat Di Bursa Efek Indonesia Periode 2006-2010. Hasil penelitian tersebut dapat disimpulkan bahwa terdapat pengaruh yang signifikan dari variable Deviden Per Shares, Return On Equity dan Net Profit Margin terhadap harga saham pada perusahaan manufaktur yang terdaftar di Bursa Efek Indonesia baik secara partial maupun simultan. 
Dari penelitian-penelitian terdahulu di atas, terdapat 3 hipotesis alternatif penelitian ini:

H1 : Earning Per Share mempunyai pengaruh yang signifikan terhadap harga saham perusahaan sektor makanan dan minuman yang terdaftar di Bursa Efek Indonesia periode 2013-2017.

H2 : Debt to Equity Ratio mempunyai pengaruh yang signifikan terhadap harga saham perusahaan sektor makanan dan minuman yang terdaftar di Bursa Efek Indonesia periode 2013-2017.

H3 : Price Earning Ratio mempunyai pengaruh yang signifikan terhadap harga saham perusahaan sektor makanan dan minuman yang terdaftar di Bursa Efek Indonesia periode 2013-2017.

H4 : Earning Per Share, Debt to Equity Ratio dan Price Earning Ratio mempunyai pengaruh yang signifikan terhadap harga saham perusahaan sektor makanan dan minuman yang terdaftar di Bursa Efek Indonesia periode 2013-2017.

\section{METODOLOGI PENELITIAN}

\section{Sumber dan Metode Pengumpulan Data}

Sumber data penelitian ini adalah bersumber dari website www.idx.co.id dan riset kepustakaan. Data tersebut berupa data sekunder dengan populasi sampel sebanyak 12 perusahaan yang bergerak dalam industri makanan dan minuman serta terdaftar di Bursa Efek Indonesia untuk periode 2013-2017.

Dari data yang dikumpulkan tersebut dipilih data terkait variable Harga saham (Y) sebagai merupakan variabel terikat dan EPS (X1), DER (X2) dan PER (X3) sebagai variable bebas. Secara statistik persamaan dari semua variable dapat dituliskan sebagai berikut:

$$
\mathrm{Y}=\mathrm{a}+\mathrm{b} 1 \mathrm{EPS}+\mathrm{b} 2 \mathrm{DER}+\mathrm{b} 3 \text { PER }
$$

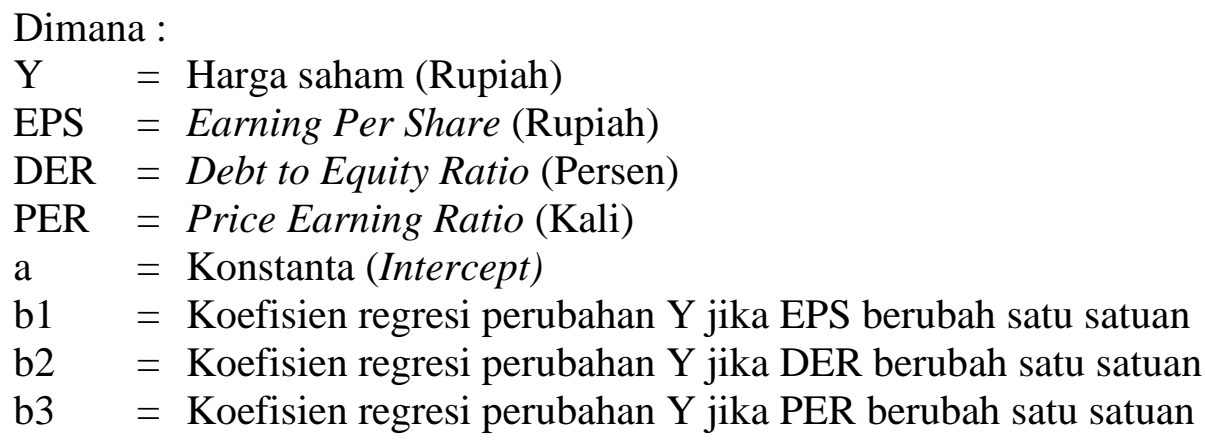

\section{HASIL DAN PEMBAHASAN}

Berdasarkan hasil penelitian diperoleh model persamaan sebagai berikut :

$$
\text { HS = 1798,397 + 0,167 EPS - 205,914DER + 79,703PER }
$$

Dari persamaan di atas dapat diperhatikan bahwa Earning Per Share berkontribusi memberikan pengaruh pada harga saham sebesar 0,167. Artinya, jika EPS naik satu satuan maka akan terjadi kenaikan harga saham sebesar 0,167 dan demikian juga sebaliknya. Price Earning Ratio (PER) juga berkontirbusi mempengaruhi harga saham sebesar 79,703 satuan. Artinya, jika PER naik satu satuan maka harga saham akan naik sebesar 79,703. Sebaliknya jika Debt to Equity Ratio (DER) naik sebesar satu satuan maka harga saham akan turun sebesar 205,914 .

Namun dari ketiga variable bebas tersebut, secara parsial hanya EPS dan PER yang memiliki pengaruh signifikan pada harga saham industri makanan dan minuman. Sedangkan DER tidak memengaruhi harga saham secara signifikan (Tabel 1). 
Tabel 1

Uji t-test

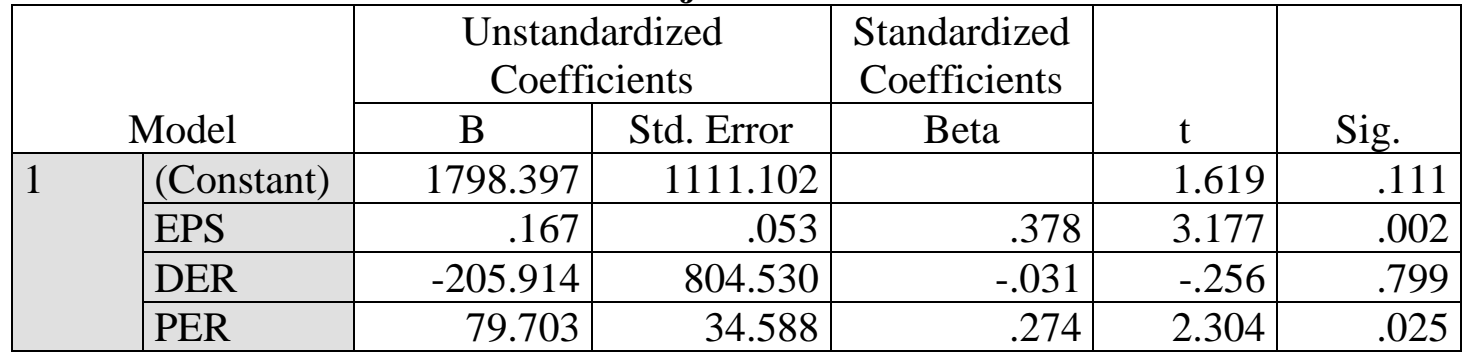

a. Dependent Variabel: Harga Saham

Sumber : hasil olahan data dengan SPSS versi 22

Jika dilihat secara bersama-sama, diperoleh hasil bahwa ketiga variable bebas secara bersama-sama memengaruhi harga saham. Hal ini diindikasikan dari nilai $\mathrm{F}$ hitung dibawah 5 persen (Tabel 2).

Tabel 2

Hasil Uji F

\begin{tabular}{|l|l|c|r|r|r|c|}
\hline \multicolumn{2}{|c|}{ Model } & $\begin{array}{c}\text { Sum of } \\
\text { Squares }\end{array}$ & df & Mean Square & F & Sig. \\
\hline \multirow{3}{*}{1} & Regression & 153709207.172 & 3 & 51236402.391 & 5.224 & $.003^{\text {b }}$ \\
\cline { 2 - 8 } & Residual & 549229251.011 & 56 & 9807665.197 & & \\
\cline { 2 - 8 } & Total & 702938458.183 & 59 & & & \\
\hline
\end{tabular}

a. Dependent Variabel: HS

b. Predictors: (Constant), PER, EPS, DER

Namun signifikansi dari seluruh variable bebas yang diuji tersebut tidak menunjukkan nilai koefisien determinasi yang besar. Nilai koefisien determinasi yang diperoleh hanya sebesar 21,9 persen. Ini menujukkan bahwa ketiga variable EPS, DER dan PER hanya mampu menjelaskan variansi dari harga saham industri makanan dan minuman sebesar 21,9 persen (Tabel 3). Sedangkan sisanya sebesar 78,1 persen dijelaskan oleh variabel bebas lain yang tidak diestimasi dalam model ini.

Tabel 3

Hasil Uji R Square

\begin{tabular}{|c|c|r|r|c|}
\hline Model & R & R Square & $\begin{array}{c}\text { Adjusted R } \\
\text { Square }\end{array}$ & $\begin{array}{c}\text { Std. Error of the } \\
\text { Estimate }\end{array}$ \\
\hline 1 & $.468^{\mathrm{a}}$ & .219 & .177 & 3131.71921 \\
\hline
\end{tabular}

a. Predictors: (Constant), PER, EPS, DER

b. Dependent Variabel: HS

\section{KESIMPULAN}

Penelitian ini memperoleh hasil bahwa Earning Per Share (EPS) secara parsial memiliki pengaruh signifikan terhadap harga saham. Sedangkan Debt to Equity Ratio (DER) secara parsial memiliki pengaruh tidak signifikan terhadap harga saham. Sebaliknya, Price Earning Ratio (PER) secara parsial memiliki pengaruh signifikan terhadap harga saham. Secara bersama-sama juga ditemukan bahwa Earning Per Share, Debt Equity Ratio dan Price Earning Ratio memiliki pengaruh signifikan terhadap harga saham perusahaan-perusahaan disektor makanan dan minuman yang terdaftar pada Bursa Efek Indonesia selama periode 2013-2017. Namun pengaruh semua variabel bebas di atas tidak dapat menjadi penjelasan perubahan harga saham. Hal ini karena nilai koefisien determinasinya hanya sebesar 21,9 
persen. Dengan demikian, disarankan perlunya studi lanjutan untuk mencari variabel-variabel bebas lainnya yang lebih berpengaruh terhadap harga saham industri makanan dan minuman.

\section{DAFTAR PUSTAKA}

Bringham, J. F. (2010). Dasar-dasar Manajemen Keuangan Jilid I dan II. Erlangga.

Harahap, S. (2004). Analisis Kritis Atas Laporan Keuangan. Edisi Pertama. Cetakan Keempat. Jakarta: PT Rajagrafindo Persada.

Hutami, R. P. (2012). Pengaruh Deviden Per Shares, Return On Equity dan Net Profit Margin Terhadap Harga Saham Perusahaan Industri Manufaktur Yang Tercatat Di Bursa Efek Indonesia Periode 2006-2010. Jurnal Nominal, Vol. 1 No. 1, Hal. 104-123.

Safitri, A. (2013). "Pengaruh Earning Per Share, Price Earning Ratio, Return On Asset, Debt Equity Ratio Dan Market Value Added Terhadap Harga Saham Dalam Kelompok Jakarta Islamic Index". Management Analysis Journal, 2.

Stella. (2009). Pengaruh PER, DER dan PBV Terhadap Harga Pasar Saham, dengan fokus penelitian pada saham perusahaan LQ-45 yang terdaftar di Bursa Efek Indonesia periode 2002-2006. Jurnal Bisnis \& Akuntansi Vol 11. (02). Hal 97-106 